\title{
EDITORIAL
}

\section{Hidup Sehat Mulai Hari ini, Masa Depan Akan Lebih Baik}

Kesehatan merupakan aspek yang sangat penting bagi kehidupan manusia. Saat ini banyak penyakit yang diderita tidak hanya disebabkan oleh virus, kuman atau bakteri, tetapi juga disebabkan oleh kebiasaan atau gaya hidup yang tidak sehat. Kehidupan yang semakin modern dan serba praktis membawa pergeseran perilaku kehidupan manusia. Gaya hidup yang tidak sehat seperti mengonsumsi makanan cepat saji, stress yang tinggi, kurang gerak, konsumsi makanan yang berlemak dan garam tinggi berdampak pada kesehatan manusia. Beberapa penelitian menunjukkan bahwa gaya hidup yang tidak sehat tersebut beresiko untuk terserang penyakit-penyakit seperti diabetes melitus, hipertensi, obesitas dan penyakit Jantung. Tulisan Said Mardani, et al menunjukkan bahwa seseorang yang terkena overweight/obesitas lebih beresiko 2 kali untuk menderita hipertensi dibandingkan dengan orang yang mempunyai berat badan normal/kurus. Demikian pula halnya dengan seseorang yang mempunyai kebiasaan mengkonsumsi makanan berlemak tinggi lebih beresiko 2 kali untuk menderita hipertensi dibandingkan dengan orang yang mengkonsumsi lemak rendah.

Mengenai bagaimana kepatuhan penderita hipertensi terhadap diet hipertensi yang dijalankan, pada jurnal ini memuat tulisan Santi Miyusliani dan Jasrida Yunita tentang Faktor Resiko yang Berpengaruh Terhadap Kepatuhan Diet Hipertensi. Hasil penelitiannya menunjukkan bahwa masih terdapat $21,7 \%$ penderita hipertensi yang tidak patuh terhadap diet hipertensi. Faktor usia merupakan faktor yang paling dominan mempengaruhi kepatuhan penderita terhadap diet hipertensi. Mereka yang berusia $>55$ tahun beresiko 5,17 kali untuk tidak patuh terhadap diet hipertensi dibandingkan dengan mereka yang berusia $\leq$ 55 tahun. Mereka yang lanjut usia (lansia) perlu mendapatkan perhatian yang lebih besar, baik oleh pihak keluarga maupun dari pihak luar khususnya dari tenaga kesehatan. Saat ini, Pemerintah sudah menyediakan tempat bagi para lansia untuk memeriksakan kesehatan secara rutin setiap bulannya di posyandu lansia.

Tulisan Nurvi Susanti dan Mitra tentang Faktorfaktor yang berhubungan dengan pemanfaatan posyandu lansia menunjukkan bahwa sebagian besar lansia belum memanfaatkan pelayanan kesehatan pada posyandu lansia. Faktor dominan yang berpengaruh terhadap pemanfaatan posyandu lansia adalah sikap lansia. Untuk itu perlu dilakukan upaya untuk meningkatkan pemanfaatan pelayanan posyandu lansia melalui promosi dan meningkatkan kualitas pelayanan di posyandu.

Selain itu tulisan tersebut di atas, pada jurnal edisi ini disajikan pula tulisan mengenai penyakit yang disebabkan oleh virus yaitu penyakit flu burung, penyakit campak dan penyakit demam berdarah dengue. Tulisan Donal dan Zainal Abidin tentang Faktor Penyebab Terjadinya Penularan Penyakit Flu Burung Pada Manusia di Kota Pekanbaru dan Kabupaten Pelalawan menunjukkan bahwa faktor lingkungan yang sangat dominan mempengaruhi penularan Avian Influenza cenderung terjadi pada keluarga yang melakukan aktivitas berternak unggas atau terpapar unggas, tempat tinggal mereka berada sangat dekat dengan kandang unggas. Upaya yang dapat dilakukan untuk mencegah terjadinya flu burung salah satunya 
adalah merubah perilaku masyarakat dalam penerapan Perilaku Hidup Bersih dan Sehat (PHBS).

Masalah-masalah Kesehatan termasuk penyakit menular dan tak menular seperti tersebut diatas, dapat diatasi dengan memberikan pelayanan kesehatan primer yang bermutu, efektif dan efisien. Tulisan Buchari Lapau tentang Strategi Epidemiologi dalam Pelayanan Kesehatan Primer menunjukkan inovasi bagaimana strategi epidemiologi dapat bermanfaat dalam pelayanan kesehatan primer. Pelayanan kesehatan masyarakat pada prinsipnya mengutamakan pelayanan kesehatan promotif dan preventif. Pelayanan promotif adalah upaya meningkatkan kesehatan masyarakat ke arah yang lebih baik lagi dan yang preventif mencegah agar masyarakat tidak jatuh sakit agar terhindar dari penyakit.

Mencegah lebih baik dari pada mengobati. Mulailah terapkan PHBS, rubahlah gaya hidup yang tidak sehat menjadi sehat dengan melaksanakan ibadah, menjaga kebersihan lingkungan, mengkonsumsi makanan yang seimbang, berolah raga yang teratur. Dengan menjaga kesehatan mulai hari ini, insya allah penyakit-penyakit akan terhindar, masa depan akan lebih baik. 